\title{
The actorness of the President of the Republic in Italian foreign policy: a quantitative narrative analysis of two case studies (1999-2013)
}

\author{
Mauro Tebaldi $^{1} \cdot$ Marco Calaresu $^{1}$ (D) $\cdot$ Alberto Purpura $^{2}$
}

Accepted: 4 July 2021 / Published online: 19 July 2021

(c) The Author(s) 2021

\begin{abstract}
In this paper, we address the topic of policy actorness in Italian foreign policy to characterize the understudied role of the President of the Italian Republic (PoR). We apply quantitative narrative analysis (QNA) as the methodological tool of our study, answering two research questions to which the academic literature has so far produced limited responses: (a) whether the PoR can be considered a relevant actor in Italian foreign policy and (b) which factors can affect the Italian PoR's relevance in foreign policy. Considering the Italian PoR's Diary as the unit of analysis and source of data, we study the two crucial cases of Ciampi's presidency (1999-2006) and Napolitano's first presidency (2006-2013). QNA allows us to quantify and compare, while maintaining an actor-centred approach, the relations of the two PoRs with the most relevant actors in foreign policy. The results of our analyses highlight the relevance of the Italian PoR figure, identifying the main areas of influence of the Italian head of state and their changes over time. We conclude providing a few hypotheses to interpret the outcomes of our analyses on the PoR's role in Italian foreign policy.
\end{abstract}

Keywords Quantitative narrative analysis · Social network analysis · Natural language processing · Policy actorness · President of the Republic · Italian foreign policy

Marco Calaresu

mcalaresu@uniss.it

Mauro Tebaldi

tebaldi@uniss.it

Alberto Purpura

purpuraa@dei.unipd.it

1 Department of Law, University of Sassari, Viale Mancini, 5, 07100 Sassari, Italy

2 Department of Information Engineering, University of Padua, Via Gradenigo, 6, 35131 Padova, Italy 


\section{Actorness of Italian foreign policy and the uncertain role of the President of the Republic}

Among the many research problems addressed by the scholars interested in Italian foreign policy, ${ }^{1}$ the topic of policy actorness ${ }^{2}$ has attracted a great deal of attention. The research on this topic extends from the identification of relevant actors to the evaluation of their relative weights and the ways and potential causes of shifts in the balance of power among the actors themselves (Kaarbo 2015). ${ }^{3}$ In this context, the numerous studies conducted have produced empirical evidence and causal explanations that sometimes disagree.

We can identify a first group of authors-who embrace the hypothesis of the prevalence of international factors over domestic ones-who argue that the state is the most critical player in foreign policy decision-making processes in Italy and elsewhere. This same group interprets the concept of state as a unitary rational actor and as an empirically observable political-territorial institution whose values and interests are considered equivalent and corresponding to those of the national community that the (nation-)state itself defends and represents (Mcclosky 1956; Waltz 1979, 1986). Based on this conceptualisation, Italian foreign policy outcomes are mainly explained as the products of the interactions among the Italian state and other nation-states.

On the other hand, we can also recognize a second group of authors who regard the state as a too generic and vague unit of analysis for an exhaustive study of the foreign policy actorness. Therefore, they adopt a more 'actor-specific orientation' (George 1993, 1994; Hudson 2005) and identify the key players, e.g., in Italian foreign policy, based on explanatory factors of domestic politics over international ones. Sometimes, these authors emphasise the decision-making power of political parties, particularly those forming the government majorities (Walston 2007b; Coticchia and Davidson 2018). In other cases, they weight the role of the prime ministers (Andreatta et al. 2002; Aliboni 2003; Greco and Matarazzo 2003; Ignazi 2004; Croci 2005a, b) or consider the influence of foreign ministers and their bureaucratic apparatus (Serra 1991; Caggiula and Benedetti 1992; Zucconi 2002; Varsori 2015).

Finally, a third group of authors proposes more complex multi-causal explanations, originating from the same dissatisfaction with the conceptualisation of the state as a collective and internally indefinite institutional actor capable of monopolising foreign policy decision-making processes (Carbone 2007; Walston 2007a; Croci 2008; Cladi and Webber 2011; Brighi 2013; Coticchia and De Simone 2016). These models tend to harmonise both analytical dimensions - international and domestic ones-assuming that, e.g., the Italian

\footnotetext{
1 Following Carlsnaes' (2002, 335) definition, the foreign policy consists 'of those actions which, expressed in the form of explicitly stated goals, commitments and/or directives, and pursued by governmental representatives acting on behalf of their sovereign communities, are directed toward objectives, conditions and actors - both governmental and non-governmental-which they want to affect, and which lie beyond their territorial legitimacy'.

2 The concept of actorness in international relations refers to "who has the right, capacity and opportunity to act' in relation to other actors in the international system (see also Groenleer and Van Schaik 2007, 972; Čmakalová and Rolenc 2012, 261).

3 We define a policy actor as any subject, public or private, individual or group, who participates in the decision-making processes to influence their outcomes. More specifically, we mainly refer to a particular type whom we call an institutional actor and distinguish from the other actors. We define an institutional actor as an individual or a group capable of acting collectively and impersonally by the home institution's rules, organisational roles and values that tend to discipline and direct the actor's action.
} 
foreign policy is the result of the interaction among different actors, whose behaviours are influenced by structural factors (the international context, the institutional constraints and opportunities), short-term factors (strategic behaviours of each actor) and cultural ones (ideas and values that shape the actors' individual preferences).

Interestingly enough, none of these analyses consider, if not incidentally (e.g. Croci and Valigi 2013), the President of the Republic (PoR from now on), i.e., the institutional player holding one the highest offices in the Italian state among the relevant actors in Italian foreign policy. If no study on Italian foreign policy qualifies the PoR among the relevant actors in this policy field, then the PoR figure must be considered a neglected and understudied topic. Furthermore, considering his coverage in the foreign analysis academic literature, one could conclude that no clear scientific proof could be assumed about the relevance of the Italian PoR's in the foreign policy decision-making process.

However, numerous studies not systematically centred on foreign policy analysis explore the PoR's political and institutional roles in the Italian political system and highlight Italian PoRs' activism in foreign policy and their capacity (in the different politicalinstitutional and international relation contexts in which they have operated) to influence to some extent the Italian foreign policy decision-making process, both in its general settings and in taking specific decisions. For example, Scaccia $(2013,101)$ states that 'no President of the Republic has refrained from making interventions on the lines of Italian foreign policy, sometimes [...] even considering himself the real architect'. ${ }^{4}$ Similarly, Lippolis and Salerno $(2013,127)$ argue that 'the tendency of presidents to express orientations and take initiatives in the field of foreign relations [...] not always coinciding with the government's orientation or aimed at conditioning it, is not new, ${ }^{5}$ Galliani, on his side $(2012,171)$, states that 'all presidents have had a significant weight' ${ }^{6}$ in Italian foreign decision-making. De Vergottini $(2011,84)$ explicitly argues that 'a sector of competencies in which the President appears to have always had a potentially freehand based on his discretionary assessments, is that of foreign policy'. ${ }^{7}$ For these authors, the Italian Constitution's articles outline a presidential figure who takes over limited functions in foreign policy and is formally subordinated to the direction of the government. ${ }^{8}$

Nevertheless, their political practice analysis shows that the PoRs have often interpreted the laconic and ambiguous constitutional law in a broad sense, informally expanding their decision-making powers and exercising those powers in total autonomy. In fact, the Italian PoRs have often developed their own foreign policy, sometimes imposing their supremacy

\footnotetext{
4 Our translation.

5 Our translation.

6 Our translation.

7 Our translation.

8 The President of the Italian Republic is elected by the parliament meeting in joint session (Art. 83) for a seven-year period. The Italian Constitution assigns to the PoR a role endowed with high political significance (Calise 2013; Tebaldi 2014a, b). However, the Constitution itself briefly and vaguely defines the PoR's powers in foreign policy. Article 87 states that 'The President of the Republic is the Head of State and represents the national unity' and establishes that the PoR 'accredits and receives diplomatic representatives, ratifies international treaties, after, when necessary, the authorisation of the Chambers'. Article 87 of the Italian Constitution also states that the PoR 'has the command of the Armed Forces, presides over the Supreme Defence Council established according to the law, declares the state of war deliberated by the Chambers'. These are presidential powers that could be relevant to foreign policy, but we regard them as proper for defence and security policy. Therefore, they are not considered in this research. The formal acts following the performance of these presidential functions are issued with the government's consent and responsibility. Article 89 of the Constitution states that 'no act of the President of the Republic is valid unless countersigned by the proposing ministers, who assume responsibility for it'.
} 
on the governing bodies or interfering with them (De Vergottini 1984, 2011), mainly through an intense and targeted use of their soft powers through their public statements (the so-called 'esternazioni', see on this Tebaldi 2005, 2011, 2014a) and moral suasion (Amoretti and Giannone 2014, 2016).

\section{Research problem, aims and research design}

As can be inferred from the previous sections, this study's research questions concern the settling of a controversial issue. It is indeed worth reflecting on whether policy analysts are right in neglecting the PoR's role in Italian foreign policy, given the PoR's limited constitutional powers compared with those of other government actors, or if it is better to believe some scholars of the Italian political system, who call the attention to the PoRs' protagonism and pre-eminence in Italian foreign policy through political practices that allow the PoR to influence the decision-making process, even opposing other government actors.

Our objective in this work is to establish some methodological, empirical and theoretical preliminary foundations aimed at analysing: (a) whether the PoR can be considered a relevant actor in Italian foreign policy and (b) which factors can affect the Italian PoR's possible relevance in the same area. We are in fact aware that to conduct any study with a theoretical aim, avoiding the investigator-induced selection bias, it is necessary to first analyse (with appropriate analytical and comparative tools) the temporal and quantitative variance of the dependent variable to hypothesise on the possible causal explanations of the observed variance (King et al. 1994, 129-135).

Consistent with these principles, our research design is organised in two stages. The first one is empirical and inductive. It consists of mapping the relationships that the PoR maintains with other actors, domestic or international, on foreign policy issues. This mapping has the following purposes: (a) quantify the PoR relations with other actors in the foreign policy domain, that is, their magnitude in terms of frequency; (b) assess the change in their amount at a given time, that is, their magnitude in terms of intensity, also in comparison with the other policy fields where the PoR's relational activity develops; and (c) examine with whom the PoR relates, that is, the domestic or the international actors in the policy domain whom the PoR more or less frequently meets. The second stage of the research is theoretical. It consists of the formulation of the hypotheses derived from the empirical analysis. These hypotheses, suggested by the observed regularities, concern the question of why the PoR expands or compresses his/her relational activity in foreign policy. By identifying the possible causal factors and hypothesising their effects, some theoretical foundations are established to explain the PoR's role in the Italian foreign policy.

The methodological assumption that connects the two stages of our research has been empirically validated in previous works on the topic (Tebaldi et al. 2018, 2019), which however exclusively concerned the role of the Italian PoR in the domestic politics and also not in a comparative venue. The above-mentioned methodological assumption stipulates that the number, the frequency, and the intensity of the PoRs relationships are reliable indicators of the relevance of the PoR's role in the domain where they occur. Indeed, the contribution of the present paper compared to the previously published works (Tebaldi et al. 2018, 2019) is to evaluate for the first time, through a comparative analysis of the interactions of two different PoRs, the relevance of the role of the PoR within the foreign policy domain (i.e., the actorness of the PoR in Italian foreign policy), also in comparison with other relevant policy areas (i.e., domestic policy), in which the PoR's relational activity develops. 


\begin{tabular}{|l|l|l|}
\hline Data (Date) & Luogo (Location) & Descrizione (Description) \\
\hline 27 Marzo 2003 & Palazzo del Quirinale & $\begin{array}{l}\text { On. Dott. Silvio BERLUSCONI, Presidente del } \\
\text { Consiglio dei Ministri, con il Sottosegretario di Stato } \\
\text { alla Presidenza del Consiglio, Dott. Gianni LETTA }\end{array}$ \\
\hline 30 Maggio 2006 & Palazzo del Quirinale & $\begin{array}{l}\text { On. Sen. Franco MARINI, Presidente del Senato } \\
\text { della Repubblica, e On. Fausto BERTINOTTI, } \\
\text { Presidente della Camera dei Deputati }\end{array}$ \\
\hline
\end{tabular}

Fig. 1 Sample extracted from the PoR's diary. Source: http://presidenti.quirinale.it/elementi/Elenchi.aspx? tipo=Visita

\section{Methodological background}

Scholars have proposed various methodological solutions to assess what variables can explain the variance of political and social actors' actions and power, even in time and space (e.g., Franzosi 1999, 132). One of the most frequently used instruments (e.g., regression models) is event counting, considered a dependent variable. Nevertheless, researchers increasingly shifted their attention from individual actors to their relationships within a network (Emirbayer and Goodwin 1994; Diani 2003; Lansdall-Welfare et al. 2017).

From this perspective, Franzosi (1998a, b, 1999, 2004, 2010, 2012) proposed a linguistic approach to text coding — known as quantitative narrative analysis (QNA hereafter) - as an alternative to the traditional systems for the evaluation and measurement of the political and social actors' actions and characteristics (Franzosi 1999, 133). QNA consists of a series of detailed procedures that enable the researcher to find answers to questions about the who, what, where, when and why of a certain event (Franzosi 2010), abandoning a variable-centred approach in favour of an actor-centred one, albeit based on a quantitative methodology (Franzosi et al. 2012, 5).

In this paper, we use the Diary of the PoR in Italy — which was first made public ${ }^{9}$ during Carlo Azeglio Ciampi's presidency (1999) ${ }^{10}$ and has been available throughout Sergio Mattarella's presidency up to the time of the writing $(2020)^{11}$ —as the unit of analysis and the source of data of the research. As shown in Fig. 1, the PoR's Diary is a digital agenda where all the daily appointments and visits of the presidents are noted, although the specific content and the duration of each appointment and visit during their term is not disclosed. Indeed, the Diary only contains short-text snippets including the date of each presidential meeting, its venue, and the roles and names of the actors with whom the president interacted.

We considered the PoR's Diary as a narrative text. In particular, we focused on the Subject-Verb-Object (SVO) triplets found in each entry of the Diary. In this specific case, each tripled showed a similar structure where the PoR (S) often met (V) one or more different actors in the form of diplomatic representatives, members of the national or a foreign government or other relevant political figures (O) according to the President's own will and for different reasons. These characteristics of the Diary's entries allowed us to employ QNA for our analysis. We also relied on some specialised software, i.e. the Program for

\footnotetext{
9 Available online at: http://presidenti.quirinale.it/elementi/Elenchi.aspx?tipo=Visita.

${ }^{10}$ Ciampi is the tenth President of the Italian Republic since the 1948 Republican Constitution came into force.

11 Mattarella is the $12^{\text {th }}$ President of the Italian Republic, still in office (fifth year) as of March 2021.
} 
Computer-Assisted Coding of Events (PC-ACE), ${ }^{12}$ to store the information extracted from the Diary and later analyse it through QNA. Other scholars relied on the presidents' diaries to carry their research (Edwards and Wayne 1990; Link and Kegley 1993), each with different goals and methodologies (Sigelman and Mcneil 1980; Best 1988, 1992).

The choice of the Diary has various advantages for empirical research. The most evident is the non-reactivity and the possibility of a diachronic analysis of the selected document as a product of institutional life. Institutional documents are indeed more suitable for quantitative analysis, especially if they are divided into interrelated homogeneous elements. Considering the latter aspect, QNA — through the so-called 'rewrite rules' (Franzosi 2010, 24) - enables a coding of the events present in the identified text source (e.g., the Diary), as well as their organisation into a vertical and hierarchical structure, composed of narrative information. Finally, the nature of the data collected from the database is suitable for approaches that are able to consider the homologous relation between semantic grammar and network models (Franzosi 2004, 100-109), which are usually used in social network analysis (SNA) (Wasserman and Faust 1994, 6) to map the relations among actors in different action areas (Diani 2003).

\subsection{The presidencies of Ciampi (1999-2006) and Napolitano (2006-2013) as crucial case studies}

In this research, we proceed to study two crucial cases of the most likely type. The study of each case should present the requirements of prominence, significance and representativeness, which justify the choice of a specific case for empirically testing (Eckstein 1975; George and Bennett 2005), according to the logic, 'if I cannot make it there, I cannot make it anywhere' (Levy 2008, 12). In our analysis, the presidency of Ciampi (1999-2006) and the first presidency of Giorgio Napolitano ${ }^{13}$ (2006-2013) were chosen based on many scholars' opinions on such institutional experiences and their supposed impact on the Italian foreign policy.

For example, Lippolis and Salerno $(2013,9)$ consider the years in office of President Napolitano as a period when the figure of the Head of the State in Italy highly influenced the political life and its development, including the foreign policy field. Tebaldi (2005, 296), for its part, notes 'the strong Europeanist vocation of President Ciampi'. ${ }^{14}$ While commenting on the use of presidential powers in both the national and the international spheres, Galliani $(2012,113)$ suggests that Napolitano's seven-year term is perhaps 'unprecedented' by any previous one. Concerning Ciampi's presidency, Galliani himself $(2012,91)$ states that 'the President of the Republic was the protagonist of [Italian] and

\footnotetext{
12 Available on-line as a freeware software at: www.pc-ace.com.

13 Ciampi was elected as the Italian Head of State on 13 May 1999, with 707 out of 1,011 votes. His election was completed on the first ballot. He earned the votes of the left-wing and the major centre-right parties. He had served as the Governor of the Bank of Italy (1979-1993), as the Prime Minister (1993-1994) and as the Minister of the Treasury of the first Prodi Government (1996-1998) and the D'Alema government (1998-1999). Napolitano was the first to be elected twice as the Head of State in Italy (in 2006 and 2013). He was first elected on 10 May 2006, with 543 out of 1,009 votes. He earned the votes of the leftwing, which had joined the Unione by that time. He had been serving as a Senator for Life since 2005 and had previously been an elected member of the legislative body in Italy (1953-1996), the Chair of the Chamber of Deputies (1992-1994), the Minister of the Interior (1996-1998) and a member of the European Parliament (1999-2004).

14 Our translation.
} 
European [foreign] policy, at least on par with the President of the Council, the Minister of Foreign Affairs and the government as a whole'. ${ }^{15}$ Cheli $(2013,439-440)$ remarks on the improved importance of the presidential role during Napolitano's first term, tracing it back to the major impact the President himself had on decision-making processes. Calise (2013, 460) considers Napolitano's seven-year term 'the most presidential one in the republican history'. Other studies also highlighted the pivotal role of President Napolitano in connection to the use of certain powers - such as moral suasion - and the overall configuration of the presidential role (Fusaro 2012; Pasquino 2012; Scaccia 2013; Tebaldi 2014a, b). Therefore, we believe the crucial case studies of Ciampi's presidency and Napolitano's first presidency are suitable for the aim of our analysis because they are expected to have the most robust sort of evidence possible in a non-experimental case study (Gerring 2007). ${ }^{16}$

\subsection{Data processing}

As a result of the previously discussed methodological choices, a 14-year period was considered, covering Ciampi's and Napolitano's presidencies. More precisely, we took into account every meeting of the two PoRs from 13 May 1999 to 30 April 2013. We obtained information about 6,793 events during both presidencies. This was collected through a scraping process ${ }^{17}$ and stored in PC-ACE. As mentioned, we applied QNA, which led us to organise the empirical research into two steps (Franzosi 2010, 60): data coding, verification and cleaning, ${ }^{18}$ and data aggregation and querying. ${ }^{19}$

\footnotetext{
15 Our translation.

16 However, this methodological choice has some limitations. Since it is a study of only two cases, it is useful for the formulation of hypotheses but does not explain the observed phenomenon, except through an extension of the comparative analysis to other cases (Smelser 1976).

17 The term scraping indicates the process of downloading pages from the web. This is often done through automated programs. In our case, we developed a script to retrieve the target information from web archives at specific URLs.

18 We relied on some natural language processing (NLP) tools to extract the information from the downloaded web pages (Manning and Schütze 1999). These software tools reduced the number of resources needed for the extraction and annotation of the data, especially for the most trivial tasks. For example, we relied on Regular Expressions (Hopcroft et al. 2006) and Named-Entity Recognition (NER) techniques to identify actor names and some of their characteristics explicitly indicated in the text. The style of the Diary made particularly effective some pattern detection strategies implemented through REs, such as the identification of the attributes of each actor indicated before his/her name, i.e., Amb. for Ambassadors or Sen. for senators. On the other hand, Collobert et al. (2011) allowed us to identify references to a specific location, person or time. Therefore, a system able to perform these actions and rely on NER and REs was developed for this project and tuned to be applied to data in Italian (see "Appendix 5"). This allowed us to automatically match each actor with his/her institutional role and with any title that was associated with his/her role. Finally, we relied on human annotators to check the automatically populated entries of our database due to variations in the writing style (Franzosi 2004, 76-79) and to add the contextual information relative to each actor, which was not available in the Diary and was useful for our research goal. After the data coding, verification and cleaning processes, we collected 7388 semantic triplets in which the PoR (S) interacts with more than 2500 actors $(\mathrm{O})$, with 2.5 commitments per day on average over 14 years.

19 The data aggregation and querying step was the core of our analysis and was conducted following the aggregation schemes in "Appendix 4". After the data was aggregated, we queried it and computed the frequencies of each category at different levels of abstraction. For instance, if the PoR met with a member of the national government, we considered this event under the domestic policy category and also under the more specific national government sub-category. Similarly, we aggregated the meetings with different representatives of foreign governments and international organisations. This step was automated to the largest extent relying on keywords explicitly characterizing certain actors within each entry of the Diary. For example, we considered the titles such as Amb. or Sen. (which univocally identified Ambassadors or Senators) or different international organisations names such as ONU, FAO etc. To conclude this process, we relied
} 


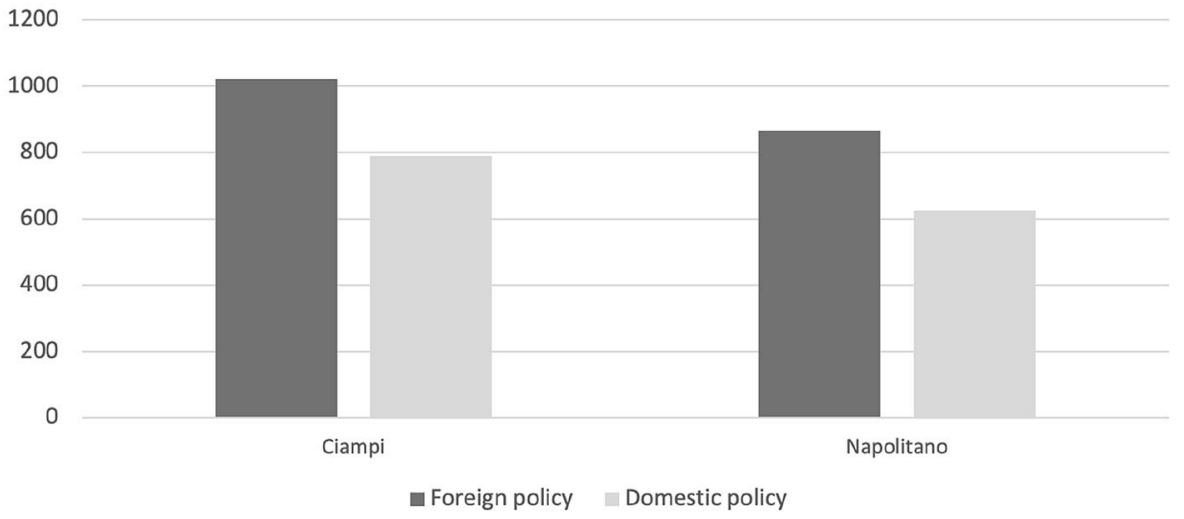

Fig. 2 President Ciampi and Napolitano's meetings related to foreign policy and domestic policy (19992013). Source: own data processing. Image: PC-ACE

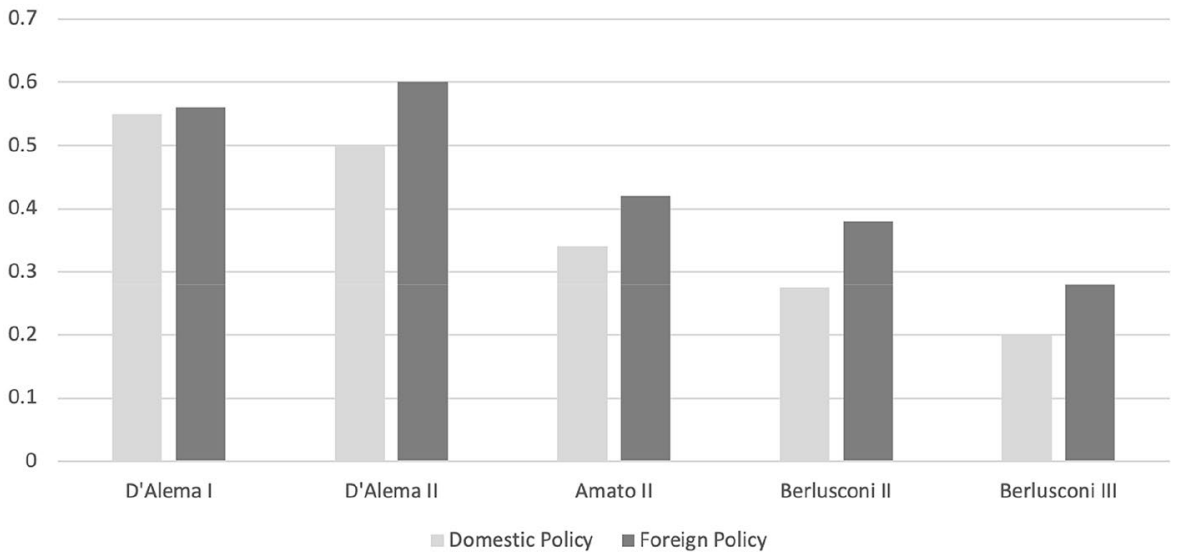

Fig. 3 President Ciampi's meetings related to foreign policy and domestic policy, normalized by government (1999-2006). Source: own data processing. Image: PC-ACE

The intrinsic relational nature of the data we collected and the data structures we used to store it allowed us to employ the Structured Query Language (SQL) to query our newly created database.

We did so through the PC-ACE software interface, which also allowed us to visualise the results of our queries. Indeed, the networks and charts in this work were created automatically through this software with minimal layout adjustments. Following the QNA

\section{Footnote 19 (continued)}

on human annotators to check for inconsistencies and complete the required missing information. When the PoR interacted with more than one actor in the same entry of the Diary we produced as many semantic triplets as the actors involved (excluding the PoR). 
methodology, we carried our analyses first aggregating the actors who interacted with the PoR at different levels of detail, i.e. considering first whether each actor could be categorised in the foreign or domestic policy area and then repeating the aggregation process distinguishing among the different sub-categories of each policy area that we identified and report in the "Appendix 4". We also considered the time variable in our analyses, comparing the results of our aggregations between different governments. These results were then reported in several egocentric networks and bar charts. To better compare the information extracted from time periods of different duration, i.e., national governments, we normalised the reported values to a uniform unit.

Concerning the egocentric networks (Knoke and Song 2008, 70), we represented the PoR as the central node, depicting the different actors he interacts with as peripheral nodes. Finally, the size of each of the peripheral nodes indicates the relative frequency of their interactions with the PoR in their specific relational sphere of action.

\section{Empirical analysis of the two crucial case studies}

In this section, we address the aforementioned questions related to (a) the quantification of the relations of the two PoRs (Ciampi and Napolitano), that is, the magnitude of their relationships in terms of frequency with a pool of diverse actors in the domestic and foreign policy domain; (b) the variation of this amount at a given time, that is, the magnitude of their relationships in terms of intensity, also in comparison with the other policy areas in which the two PoRs' relational activity develops; and (c) the total number of internal and international actors in foreign policy with whom the presidents are connected.

Concerning (a), it is possible to compare the absolute frequency of the two presidents' meetings with the actors in the areas of foreign and domestic policy, with particular reference-concerning the latter-to the state's three main powers, namely the executive, legislative and judicial branches (see "Appendix 2 and 3"). As shown in Fig. 2, in both cases, the number of presidential relations related to foreign policy (1,022 events for Ciampi, 866 for Napolitano) exceed those related to domestic policy (789 for Ciampi, 626 for Napolitano), net of the total number of meetings held by the presidents in their respective seven years of office.

Concerning (b), by specifically examining in Figs. 3 and 4, the development of the two presidents' relationships with foreign and domestic policy actors during their respective mandates - that is, by analysing the intensity of the above-mentioned normalised relations for the duration of each government during the 7-year term-we can observe a high consistency of the empirical data found in the previous observation. Considering the eight different Italian governments that followed one another in the analysed period, we find a substantial equivalence between the frequency of meetings of the Head of State with the actors in domestic and foreign policy only in one case: the D'Alema I government, during the first year of Ciampi's presidential mandate. During all the other governments (D'Alema II, Amato II, Berlusconi II, Berlusconi III, Prodi II, Berlusconi IV and Monti), foreign policy - at least from the perspective of the magnitude of relations with respect to domestic policy - seems to have been the main relational aim of the two presidents.

Concerning (c), the egocentric networks proposed in Figs. 5 and 6 allow us to analyse the complexity of foreign policy actors-domestic and international-with whom the two presidents have interacted during their respective mandates. The characteristics of these networks, on one side, clearly show that both presidents are engaged in relationships with 


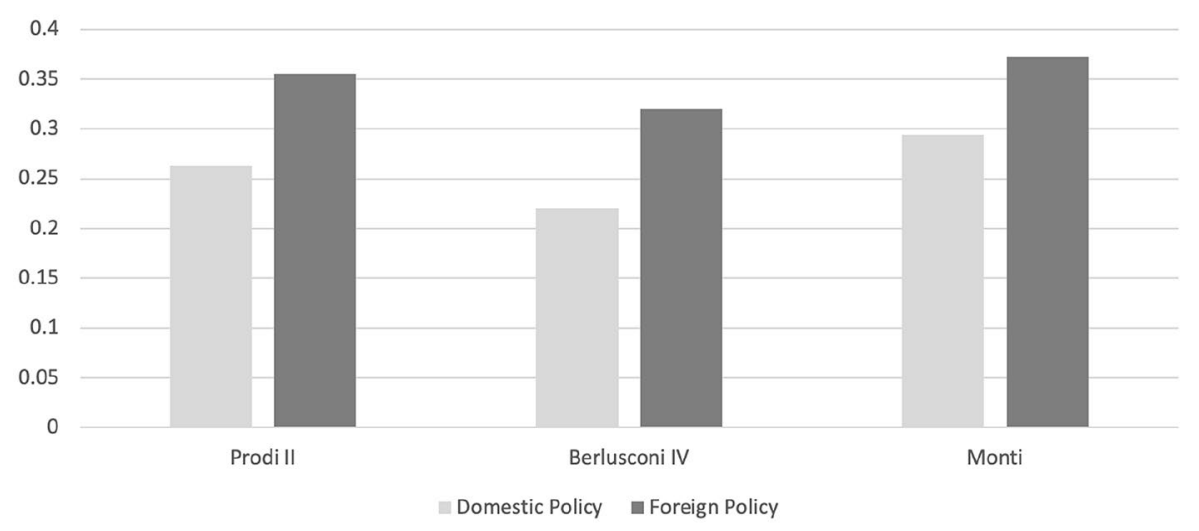

Fig. 4 President Napolitano's meetings related to foreign policy and domestic policy, normalized by government (2006-2013). Source: own data processing. Image: PC-ACE

a large and diversified number of actors related to the foreign policy domain (from foreign state representatives to national government representatives, from international organisations to representatives of the European Union). On the other side, both presidents show a quantitative preference, in terms of the absolute number of meetings, for the representatives of foreign states (with 567 total meetings for Ciampi and 440 for Napolitano over the seven-year period), for the Italian national government representatives (229 and 158 meetings, respectively) and international organisations' representatives (77 and 60, respectively).

By further breaking down the first of the aforementioned analytical categories- the most significative in terms of frequency-we observe that if on the one hand, both presidents relate more frequently with their international counterparts, that is, with other state heads (Ciampi has 241 total meetings in this category compared with Napolitano's 189 meetings), on the other hand, presidential choices are increasingly diversified as the scale of absolute frequency of meetings goes down. For example, if Ciampi preferred to meet with Italian state diplomatic corps members, Napolitano favoured his relationships with the representatives of the foreign state diplomatic corps (see "Appendix 4" for further details on this matter).

The two bar charts in Figs. 7 and 8, normalised by government, also allow us to assess the intensity of Ciampi's and Napolitano's year-by-year relationships under different analytical categories in which we break down the foreign policy domain. From this perspective, compared with previous research findings on the relational capacity of the Head of State in domestic politics (Tebaldi et al. 2018, 2019), both presidents do not seem-willing or able - to modulate their accordion action during their 7-year term. In fact, the empirical evidence shows that both presidents do not adopt different strategies from year to year but adopt a similar relational behaviour that is consistent with that of any government during their mandate. It is possible to observe how year after year, Napolitano's presidential attention always puts his relations with foreign states, the national government, international organisations and the European Union representatives in the same (decreasing) order. Regarding Ciampi, there is a substantial convergence with Napolitano, with a relative absence of significant accordion modulations during his seven-year period (see "Appendix 4" for further details). The most significant variation that can be observed in Ciampi's 


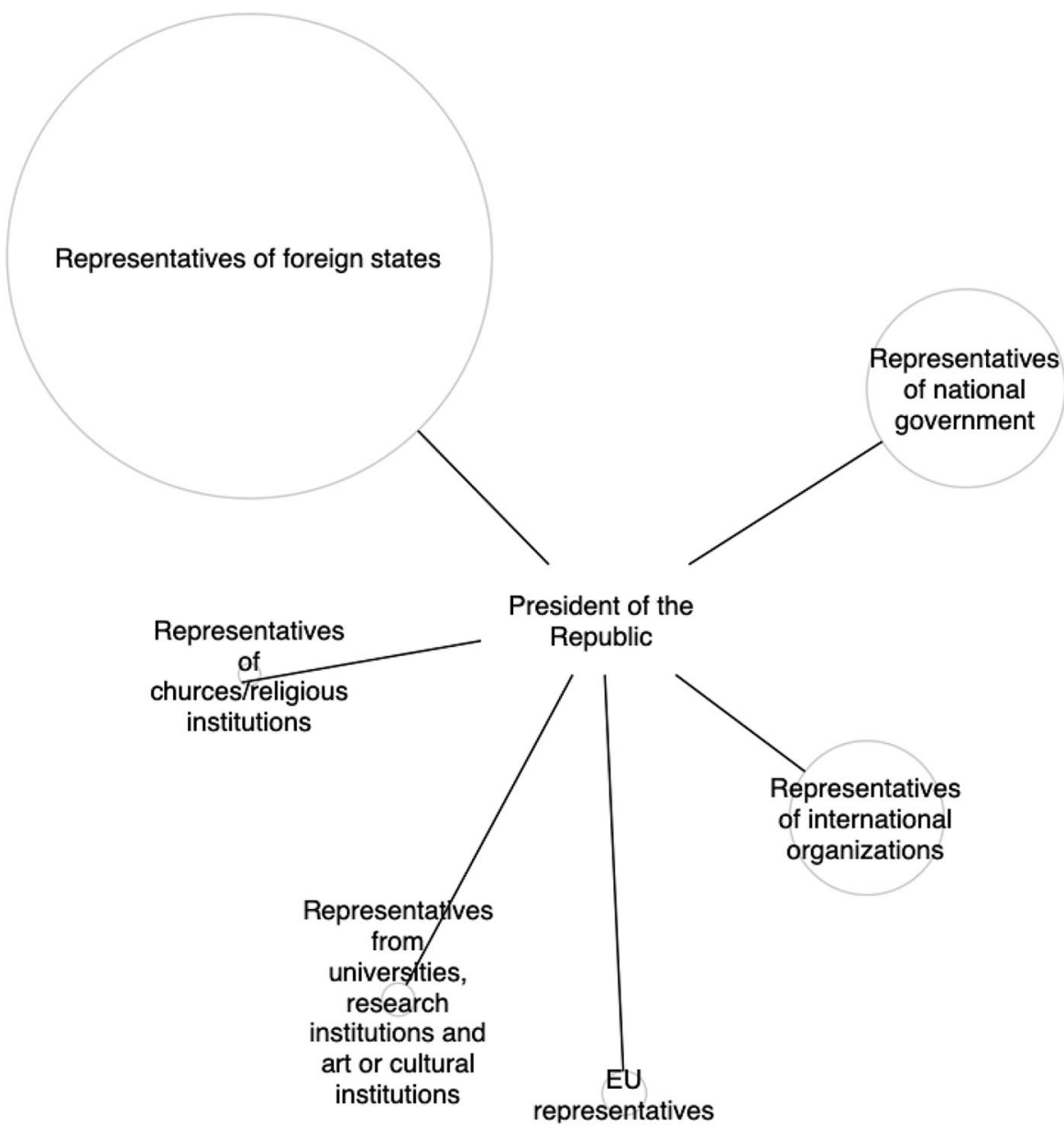

Fig. 5 President Ciampi's meetings with foreign policy actors (1999-2006). Source: own data processing. Image: PC-ACE

seven-year term concerns his first year, which he devotes more intensely to international organisations than to the national government.

Instead, the accordion trend returns to characterise the relational interests of the presidents if we look at the bar charts, normalised by government, in Figs. 9 and 10, showing the relations between Ciampi and Napolitano and those that are considered the four ministries that form the state's political-administrative backbone, for both foreign and domestic policy (Tebaldi et al. 2018, 2019): on the one hand, the Ministry of Foreign Affairs and International Cooperation; on the other hand, the Ministries of Economy and Finance, Interior and Justice. With more details, as far as Ciampi is concerned, the intensity of his meetings with the Ministry of Foreign Affairs and International Cooperation during the Berlusconi II government particularly stands out (45 meetings in 1412 days of government) compared with 33 meetings with the Ministry of Economy and Finance, 16 with the Ministry of the Interior and 11 with the Ministry of Justice. 


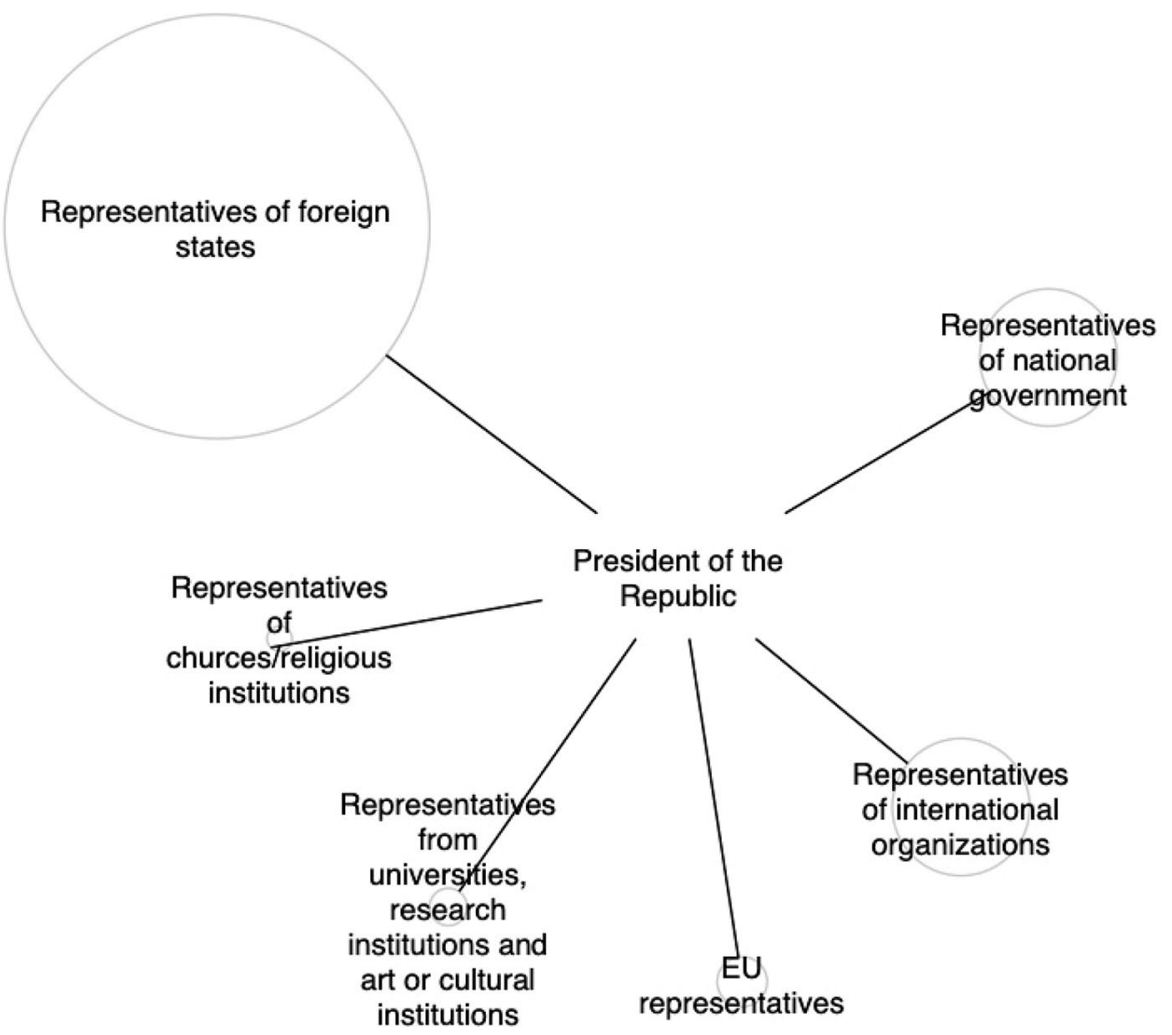

Fig. 6 President Napolitano's meetings with foreign policy actors (2006-2013). Source: own data processing. Image: PC-ACE

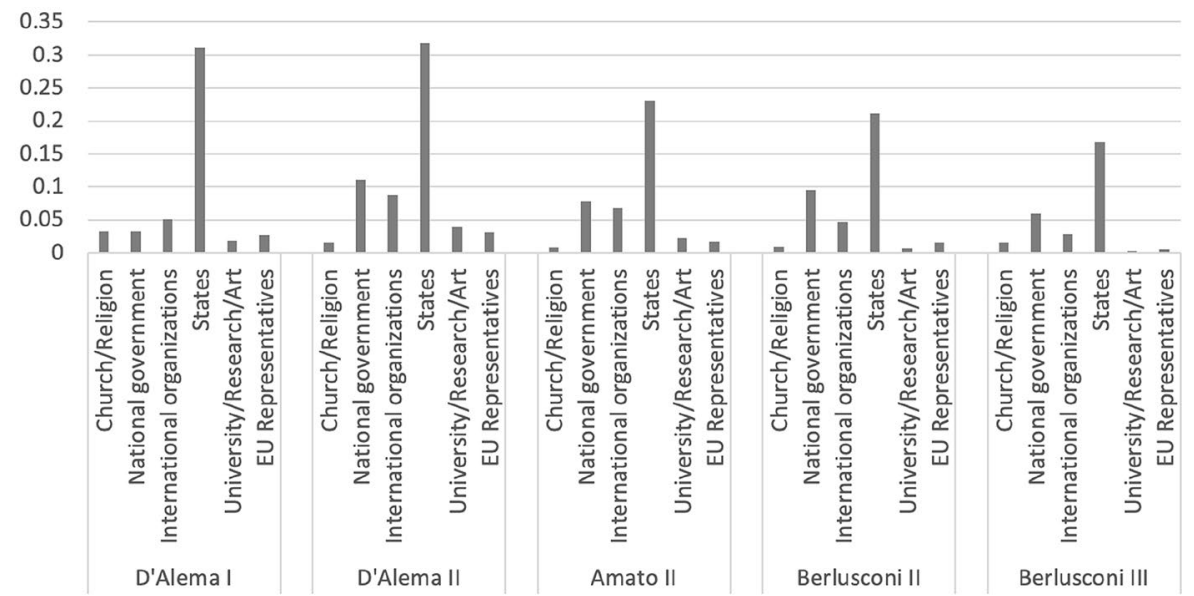

Fig. 7 President Ciampi's meetings with foreign policy actors, normalized by government (1999-2006). Source: own data processing. Image: PC-ACE 


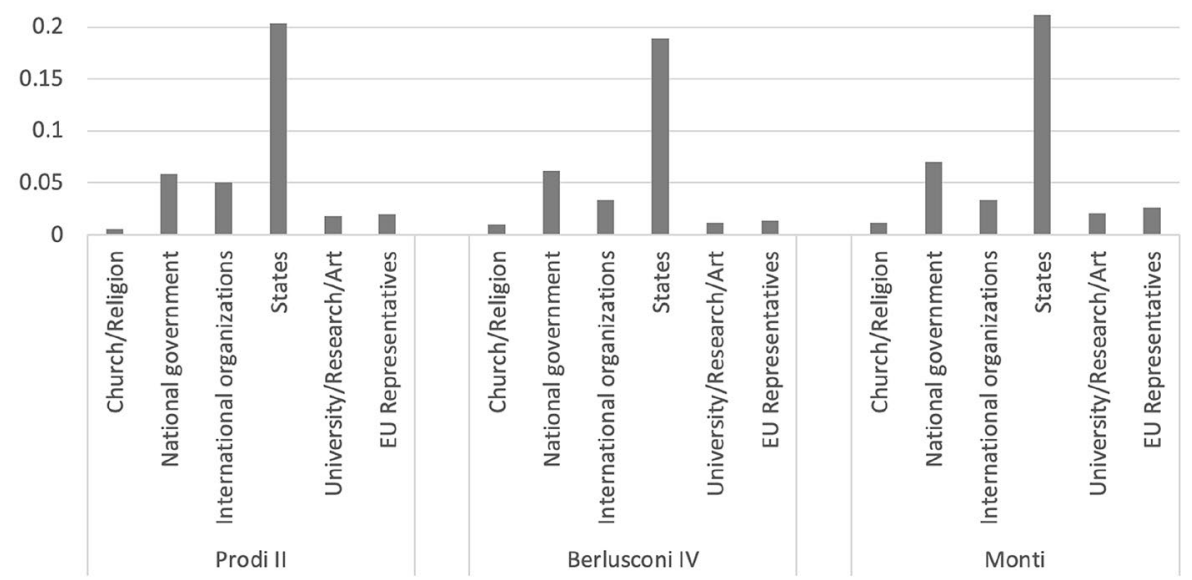

Fig. 8 President Napolitano's meetings with foreign policy actors, normalized by government (2006-2013). Source: own data processing. Image: PC-ACE

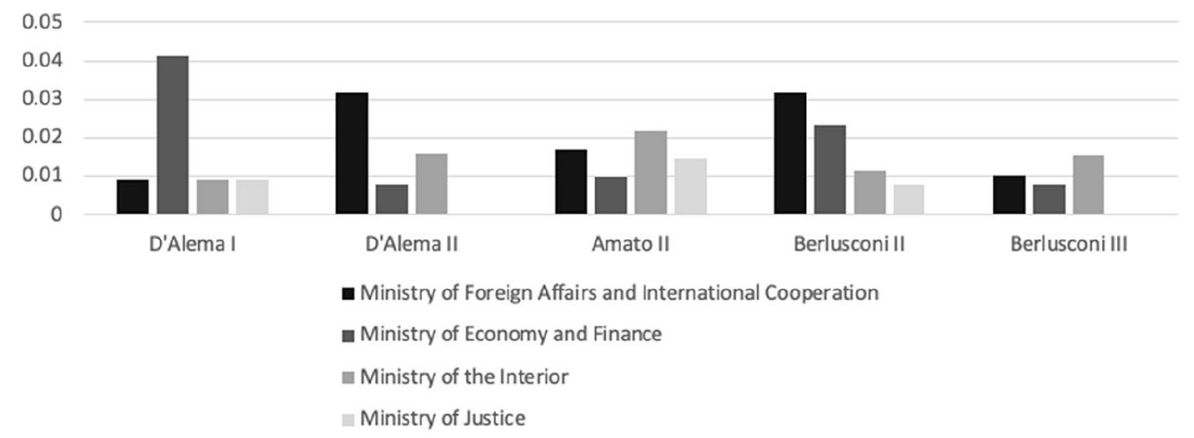

Fig. 9 President Ciampi’s meetings with Government Ministries, normalized by government (1999-2006). Source: own data processing. Image: PC-ACE

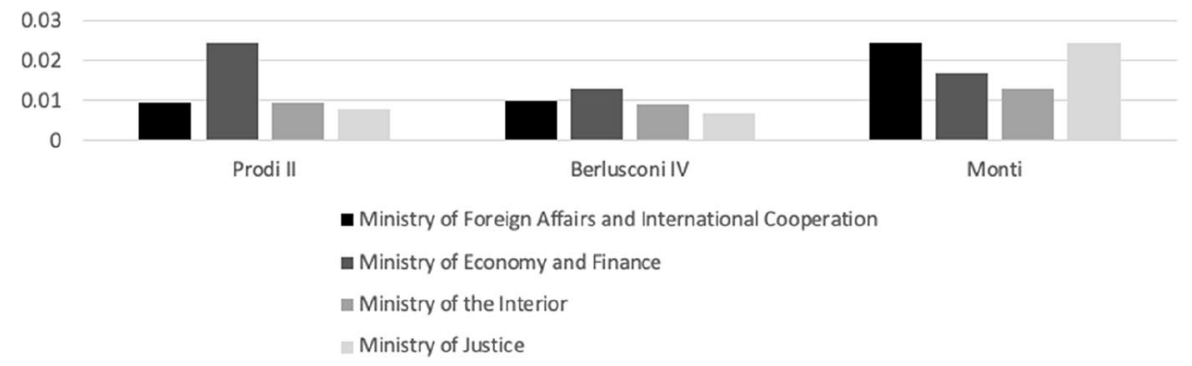

Fig. 10 President Napolitano's meetings with Government Ministries, normalized by government (20062013). Source: own data processing. Image: PC-ACE

The shift in Ciampi's relational interest is sharp if we observe the trend of his first year in office, during the D'Alema I government, with only two meetings reserved for the 
Ministry of Foreign Affairs (in 218 days) and 20 total meetings dedicated to the three most relevant ministries of domestic policy, all at the same level of intensity. As far as the foreign policy domain is concerned, the relevance of the Ministry of Foreign Affairs is empirically clear if we consider that even compared with other important ministries, such as the Ministry of Justice (with which Ciampi does not even hold a meeting during the D'Alema II and the Berlusconi III governments), the Ministry of Foreign Affairs always remains above a certain threshold of relational interest, that is, it never disappears from the Presidential Diary.

Turning to Napolitano, it can be observed that the Monti government—during which he intensifies the frequency of his interactions - has as privileged participants once again the Ministry of Foreign Affairs, in conjunction with the Ministry of Justice (13 meetings with both in 530 days). In comparison, during the Prodi II and the Berlusconi IV governments, the normalised differences seem more nuanced, with a lower overall activity of Napolitano (respectively, seven and 13 meetings with the Ministry of Foreign Affairs, although this time, in 722 and 1,287 days). In Napolitano's case, it also seems complicated to consider the Ministry of Foreign Affairs as quantitatively irrelevant, even compared with the other key ministries of the country's government.

\section{Discussion of empirical data and preliminary hypothesis}

The empirical analysis presented in the previous section provides strong evidence supporting the assertion that the PoR's relational activity in the Italian foreign policy is relevant. The relevance is evident in quantitative terms if we examine the data regarding the three dimensions of our research.

If we consider (a) the frequency of the relationships that the PoR maintains with the actors in the foreign policy domain compared with the actors in the domestic policy area, in both case studies, the amount of the former exceeds that of the latter. Shifting the analytical focus on (b), the intensity of the aforementioned relations normalised by the duration of each government in office during the two seven-year presidential terms, the foreign policy domain is confirmed as the prevalent relational arena of both Ciampi and Napolitano. Finally, if we turn our attention to (c), we observe a critical and constant role of the PoR in the field of international relations of the Italian state, as well as the variability of the PoR's relations with the Ministry of Foreign Affairs compared with the other most important Italian ministries.

Based on this empirical evidence, we can therefore argue that the PoR's relational activity in the foreign policy domain is comparatively more frequent and more intense than the relational activity that he conducts in the domestic policy domain, regardless of the political colour of governments. The PoR's relational activity in the foreign policy domain occurs mostly with international actor, rather than domestic ones. The PoR's relational activity with the Ministry of Foreign Affairs, in comparison to that with the other main Italian ministries, is always consistent but not always prevalent and is subject to a certain degree of variability, depending on the political colour of the government.

Under these arguments, it is difficult to challenge the fact that the PoR is a relevant actor in Italian foreign policy, at least in terms of the prevalence and the intensity of his relations in the foreign policy field if compared with the total amount of his relational activity. The relevance detected by our analysis is purely a quantitative one and follows from an actor-centred research strategy, which examines the variance of the phenomenon from the 
perspective of the overall relations maintained by a single actor. Therefore, we can state that the foreign policy domain is the predominant relational policy field of the two Italian PoR subjects of this study. However, since our methodological assumption stipulates that the PoR relationships are reliable indicators of the relevance of his role in the policy field where they occur, and other analyses have demonstrated the PoR's relevant role in the Italian political system based on the number of relations that he maintains with other politicalinstitutional actors (Tebaldi et al. 2018, 2019), following this argument, it can be correctly stated that his role is similarly relevant in the foreign policy field, where he maintains his most frequent and intense relations.

These inductive assertions suggest four preliminary competing hypotheses about the reasons for the relevance of the PoR's role in Italian foreign policy. Two hypotheses explain the PoR's role from a shared politics-oriented perspective (politics determines PoR actorness).

The first hypothesis is metaphorically represented by the image of the presidential accordion, which describes the fluctuating relevance of the PoR's role in the different evolutionary phases of the Italian political system. According to it, the oscillating relevance of the PoR's role would mainly depend on the strength/weakness of the party system and/or the robustness of the government/parliamentary majority connections. The constantly increasing political and institutional role of the PoR during the Second Republic, including Ciampi's and Napolitano's role in foreign policy, could therefore be interpreted as a response to the crisis of the party system and/or the instability of the government/parliamentary majority connections (Pasquino 2012; Tebaldi 2014a). If this were true, a diachronic comparison extended to all the presidents of the Italian Republic, starting from 1948, should offer a differentiated frame, with an alternation of phases where the PoR increases or decreases his role in foreign policy, depending on the strength of the party system and/or the degree of stability of the government/parliamentary majority connections.

The second hypothesis (Calise 2013; Amoretti and Giannone 2014; Palladino 2015) explains the increasing role of the PoR as a product of the processes of personalisation (Calise 2013), presidentialisation (Poguntke and Webb 2007) and mediatisation of politics (Mazzoleni and Schulz 1999; Esser and Strömbäck 2014), which have affected the Italian political system from the 1990s onwards. The theoretical assumption shared by these studies is that the systemic characteristics of the abovementioned processes constitute a single explanatory factor that influences the evolution of the PoR's role in the Italian political system. Based on this theoretical approach, the PoR's relevance in Italian foreign policy could therefore be explained, on the one hand, by the increase of his institutional autonomy and legitimacy, and on the other hand, through the redefinition and the innovative use of his communicative powers (Tebaldi 2014b; Grimaldi 2017) in the mediatised public sphere. Similar to the first hypothesis, the validation or the refutation of this second hypothesis would require a comparative strategy based on a long-term diachronic analysis, capable of perceiving the differences in the PoR's relevance in Italian foreign policy before and after the 1990s.

The third hypothesis follows a polity-oriented perspective (polity determines PoR actorness). It assumes that national foreign policy, as well as the strategies and the actors' behaviour in the foreign policy domain, mainly depend on explanatory factors acting at the international level. Following this hypothesis, the PoR's importance in Italian foreign policy could result from the balance of power between states and the consequent models of international relations. Both these factors would have shaped and selected the relevant actors in Italian foreign policy, placing the PoR among the members of the Italian foreign policy network on a permanent basis. To verify this hypothesis, the empirical analysis 
should identify the international conjunctures that would have determined, from 1948 onwards, any changes in the frame of the relevant Italian foreign policy actors and further explore which specific international factor, if any, would tend to promote the PoR as a relevant actor in the Italian foreign policy network.

The last hypothesis is based on a policy-oriented perspective (policy determines PoR actorness). Following this research perspective, we could hypothesise that the presence of the PoR among the relevant actors in Italian foreign policy is an issue that ultimately would depend on the foreign policy itself. More specifically, it would depend on how the aims and the traditions of Italian foreign policy tend to shape a policy arena where some actors, including the PoR, are regularly required to attend as relevant actors in one or more decision-making process phases. This would determine a sort of functional specialisation of the PoR's role in Italian foreign policy. If this hypothesis was confirmed, the PoR's role in Italian foreign policy would tend to replicate itself with a certain continuity and persistence throughout the institutional life of the presidency of the Republic from 1948 onwards, regardless of the strength of the parties and the stability of the government coalitions, the presidents' personal qualities and tendencies towards personalising the role, and the international crises and the balance of power in international relations.

\section{Conclusions}

In this work, we addressed the understudied topic of the actorness of the PoR in Italian foreign policy. For this purpose, we focused on two research questions to which the academic literature has so far produced limited responses: (a) whether the PoR can be considered a relevant actor in Italian foreign policy and (b) which factors can affect the Italian PoR's possible relevance in the foreign policy decision-making process. To answer these research questions, we studied the two crucial cases of Ciampi's and Napolitano's (first) presidency. We applied QNA as the methodological tool of our analysis and considered the Italian PoR's Diary as the unit of analysis and source of data. Based on the relationships that the PoR maintained with other political-institutional actors, his role in the foreign policy appeared as relevant, at least from a quantitative point-of-view. As far as the reasons for the relevance of the PoR's role in Italian foreign policy are concerned, four competing hypotheses have been suggested and preliminarily discussed.

Regarding the first one, the PoR's relevance in the foreign policy domain during the Second Republic in Italy could be interpreted as a response to the crisis of the party system and/or the instability of the government/parliamentary majority connections. The second hypothesis describes the rising role of the PoR as a product of the processes of personalisation, presidentialisation and mediatisation of politics, which have affected the Italian political system from the 1990s onwards. Following the third hypothesis, the PoR's importance in the Italian foreign policy decision-making process could be the consequence of the balance of power between states and/or the applied models of international relations over the last 30 years. Finally, our fourth hypothesis assumes that the actorness of the PoR would depend on how the aims and the traditions of Italian foreign policy tend to shape a policy arena where some actors, including the PoR himself/herself, are constantly required to attend as relevant actors in foreign decision-making processes.

Regarding the methodological contribution of this work, we used QNA to adopt an actor-centred approach in foreign policy analysis, relying at the same time on a quantitative methodology. QNA is, in fact, a useful tool with which to find answers to the basic five Ws 
structure of narrative (Who-What-When-Where-Why), which enable scholars to transform the words contained in a text source into numbers, and then go back to words with an actorspecific orientation.

Furthermore, QNA allowed us to provide different insights compared to those we could have obtained through other statistical analyses of event counts. First, since analyses based on event counts do not generally consider the meaning of the interactions between the actors involved, they would not have allowed us to produce either the organ pipe charts of Figs. 2, 3, 4, 7, 8, 9 and 10 (the President's relational intensity) nor the egocentric network graphs of Figs. 5 and 6 (the frequency of the presidential meetings), which we produced using QNA. Second, contrary to the traditional statistical analysis of time series, the use of QNA - in association with the SNA — enabled us to assess short sampling periods, reducing the risk of masking intra-sample time variations.

Nevertheless, it is important to highlight two main limitations of this work and what we believe could be the future directions in this field of study.

First, it must be stressed that we have conducted an empirical study of two crucial cases of the most likely type, focusing on the presidency of Ciampi (1999-2006) and the first presidency of Napolitano (2006-2013). Although these two cases have been chosen on the basis of their prominence, significance and representativeness, our research should be considered preliminary and exploratory as far as it concerns the causal mechanisms operating in the four abovementioned alternative hypotheses about the PoR's relevance in the foreign policy domain, during the Second Republic. Future research should extend the comparison to more presidential mandates (ideally covering all the presidents of the Italian Republic who have been in charge from 1994 to 2020), to empirically testing the hypotheses with a quantitative and/or qualitative comparative analysis (QCA), (e.g., (see Schneider and Wagemann 2010)).

An even more in-depth quantitative empirical analysis could cover all the presidents in the country's history (1948-2020), testing the causal hypotheses with a comparison among all the presidents of the first (1948-1994) and the second Italian Republic (1994-2020). This type of comparison-with a clear-cut before and after the radical change happened in the national political system (Pasquino 2012) — would allow researchers to isolate better and eventually test some crucial intervenient or even independent variables, such as the characteristics of the electoral system, the characteristics of the party system and/or some of the most relevant events of an exogenous/international nature (the fall of the Berlin Wall, Italy's entry into the European monetary union, the 9/11 attacks, etc.).

Second, it should be pointed out that in this work, the empirical research was restricted to the Diary of the Italian PoR as the unit of analysis and the source of data, which only include the date of each presidential meeting, its venue, and the names and the roles of the actors with whom the presidents networked, without any reference to, e.g., what the President discussed, or the total duration of the meeting. Moreover, to thoroughly test the hypotheses mentioned above, future research on the topic should also consider the presidential 'soft types of power', based on the President's personal skills and resources and implemented through formal and informal channels of communication (Giannone and Cozzolino 2021). In fact, according to several scholars (Calise 2013; Amoretti and Giannone 2014), the most significant power of the Italian Head of State would be precisely the use of these informal powers, such as moral suasion, freedom of speech and expression of his/her views on any possible political issue (Grimaldi 2011, 2017; Tebaldi 2014a, b). 


\section{Appendix 1}

In the following scheme we report examples of semantic triplets extracted from the PoR's Diary.

(Event:

(Subject: Presidente della Repubblica),

(Verb: incontra),

(Object: On. Silvio BERLUSCONI),

(Domestic Politics:

(Political Organizations:

(Political Parties: Leader di partito),

(Government: Berlusconi II),

(Parliamentary/Extra-parliamentary: Parlamentare),

(Government/Opposition: Government),

(Majority/Minority: Maggioranza),

(Party Name: Forza Italia)

) ,

(Legislative Power:

(Chamber of Deputies: Leader del gruppo di maggioranza)

),

(Date: 27 Marzo 2003),

(Location: Palazzo del Quirinale)

)

(Event:

(Subject: Presidente della Repubblica),

(Verb: Incontra),

(Object: On. Sen. Franco MARINI),

(Domestic Politics:

(Political Organizations:

(Political Parties: Leader di partito),

(Government: Prodi II),

(Parliamentary/Extra-parliamentary: Parlamentare),

(Government/Opposition: Governativo),

(Majority/Minority: Maggioranza),

(Party Name: Partito Democratico)

) ,

(Legislative Power:

(Senate of the Republic: Presidente del Senato della Repubblica)

) ,

(Date: 30 Maggio 2006),

(Location: Palazzo del Quirinale) 


\section{Appendix 2}

In Table 1, we report the labels used in the figures of the manuscript in order to provide a correspondence with the original institution names in Italian language. This choice was made in order to prevent misleading translations of the labels, which often refer to institutions, or entities that are unique for the Italian political system, and to facilitate the reproducibility of our research in other languages than English and Italian. Finally, in all the figures, "Presidente della Repubblica" has always been translated as "President of the Republic" (PoR).

Table 1 Original coding scheme and labels reported in Figs. 2, 3, 4, 5, 6, 7, 8, 9, 10

\begin{tabular}{ll}
\hline Italian institution names & Labels reported in figures \\
\hline Politica interna & Domestic policy \\
Politica estera & Foreign policy \\
Rappresentanti di stati esteri & Representatives of foreign states \\
Rappresentanti del governo nazionale & Representatives of national government \\
Rappresentanti di chiese/istituzioni religiose & Representatives of churches/religious institutions \\
Rappresentanti di organizzazioni internazionali & Representatives of international organizations \\
Rappresentanti dell'Unione Europea & EU representatives \\
Rappresentanti di università, enti di ricerca o associazi- & Representatives from universities, research insti- \\
oni artistiche o culturali & tutions and art or cultural institutions \\
\hline
\end{tabular}

\section{Appendix 3}

In Table 2, we report the names of the considered ministries as they possibly change under different governments (1999-2013). We decided to aggregate different labelled ministries referring to the same policy area under the same label in our coding scheme (the labels are shown in detail in "Appendix 4"), reporting here all the names used in the PoR's Diary to refer to them.

\section{Appendix 4}

In the following scheme we report in bold all the recognized categories at different aggregation levels used in the data coding stage. The terms not in bold represent the values which can be added under each category. 


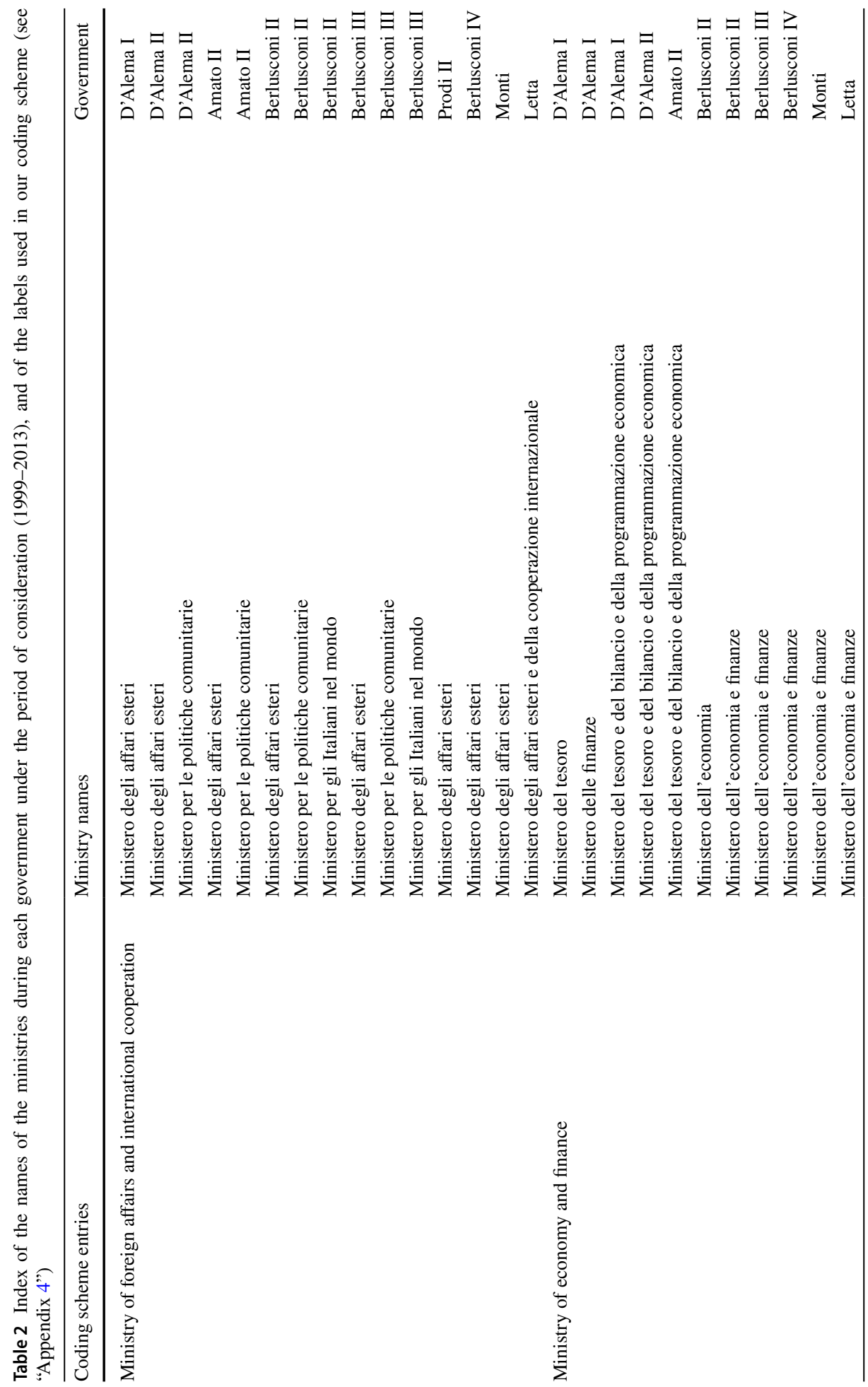




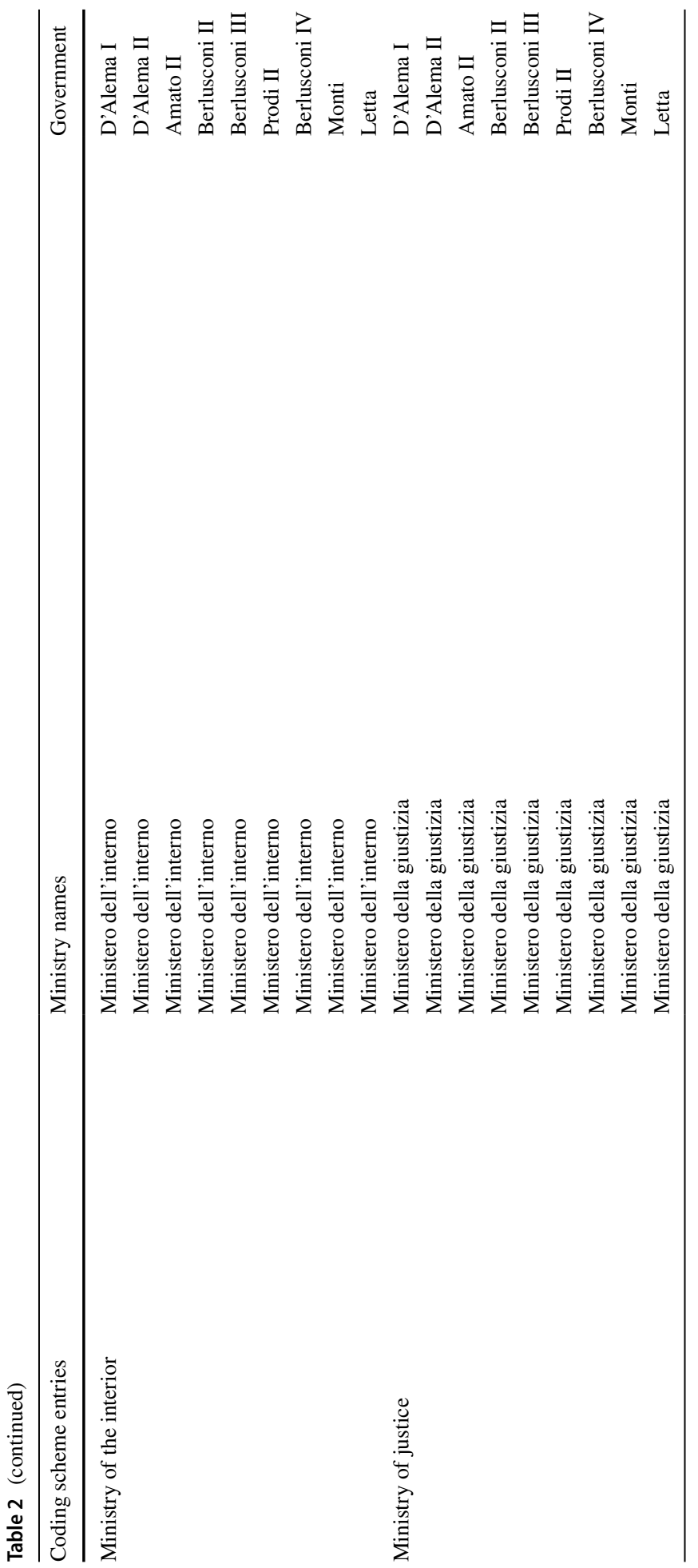


(Event:

(Subject: Presidente della Repubblica),

(Constitutional Court: Presidente della corte costituzionale, Membro della corte costituzionale, Presidente emerito della corte costituzionale, Vice presidente emerito della corte costituzionale), (Court of Cassation: Primo presidente della corte di cassazione, Primo presidente aggiunto della corte di cassazione, Presidente aggiunto della corte di cassazione, Procuratore generale della corte di cassazione, Procuratore generale militare della corte di cassazione, Procuratore nazionale antimafia, Procuratore generale aggiunto della corte di cassazione, Membro della corte di cassazione), (Presidente del consiglio nazionale forense: Avvocato generale dello stato), (Ordinary Court: Presidente del tribunale, Procuratore della Repubblica), (Appeal Court: Procuratore generale della corte d'appello, Presidente della corte d'appello), (National Association of Magistrates: Presidente dell'associazione nazionale magistrati), (Council of Tax Courts: Presidente del consiglio di presidenza della giustizia tributaria), (Union of Penal Chambers: Presidente dell'unione camere penali), (Organismo Unitario Avvocatura Italiana: Presidente dell'organismo unitario avvocatura italiana), (Regional Administrative Court: Presidente del tribunale amministrativo regionale, Membro del tribunale amministrativo regionale, Presidente emerito del tribunale amministrativo regionale)),

(Defense and Security: (Armed Forces: Aeronautica militare, Esercito italiano, Marina militare), (Police Forces: Polizia di stato, Polizia penitenziaria, Corpo forestale dello stato, Corpo nazionale dei vigili del fuoco, Corpo delle capitanerie di porto, Arma dei carabinieri, Guardia di finanza), (Control and Coordination Units: Comando supremo militare italiano, Consiglio supremo di difesa, Stato maggiore della difesa, Protezione civile, Comitato parlamentare per la sicurezza della Repubblica, Segretario generale della difesa), (Information Agency for the Security of the Republic: Dipartimento delle informazioni per la sicurezza (from 2008), Agenzia informazioni e sicurezza esterna (from 2008), Agenzia informazioni e sicurezza interna (from 2008), Sevizi segreti (only 2006-2007)))),

(Local Government Bodies: (Regional: Regione, Presidente della regione, Consiglieri regionali, Membri giunta regione, Presidente consiglio regionale), (Local: Provincia, Presidente della provincia, Consiglieri provinciali, Membri giunta provinciale, Presidente del consiglio provinciale, Comune, Sindaco, Consiglieri comunali, Membri di giunta comunale, Presidente consiglio comunale, Città metropolitana, Sindaco città metropolitana, Consigliere città metropolitana, Membro conferenza metropolitana, Circoscrizione, Presidente di circoscrizione, consigliere di circoscrizione), (Territorial Offices of the Government: Prefetto, Questore, Comando vigili del fuoco), (Territorial Coordination Bodies: Presidente ANCI, Presidente coordinamento territoriale regionale, Presidente coordinamento provinciale)),

) ,

(Foreign Policy:

(States: Capo di stato, (President of the Republic: Capo di governo, Non capo di governo), (Prime Minister: Capo di stato, Non capo di stato), (Monarch: Capo di governo, Non capo di governo), Ministro degli esteri di stato estero, Altro ministro di stato estero, (Ambassador or Other Diplomatic Representative from a Foreign State: Ambasciatore, Console), Membro del corpo diplomatico statale, Presidente del parlamento di stato estero, Rappresentante potere legislativo di stato estero, Leader partito o movimento di stato estero), 
(International Organizations: (European Union Representative: Presidente dell'unione europea, Presidente della commissione europea, Commissario europeo, Presidente della corte europea dei diritti dell'uomo, Presidente del parlamento europeo, Parlamentare europeo, Componente commissione parlamento europeo, Componente gruppo parlamentare europeo, Presidente della banca centrale europea, Leader di movimento o di partito politico europeo, Presidente dell'assemblea parlamentare del consiglio d'Europa, Segretario generale del consiglio d'Europa, Presidente del consiglio europeo, Presidente della banca europea per gli investimenti), (ONU Representative: Segretario generale dell'ONU),

(International Monetary Fund Representative: Presidente del FMI), (World Bank Representative: Presidente della banca mondiale), (OCSE Representative: Presidente dell'assemblea parlamentare dell'OCSE), (NATO Representative: Segretario generale della NATO), Rappresentante altre organizzazioni internazionali non governative),

(Churches/Confessions: (Head of Church: Capo dello stato, Non capo dello stato), (Member of Ecclesiastical Organization: Membro diplomazia, Non membro della ), diplomazia))

(Date: «Date of Event»),

(Location: «Place of Event»)

) .

\section{Appendix 5}

The parser used to process the data in the Diary was written in Python and performed all the tasks necessary to identify the names and the roles of the actors with whom the President of the Republic interacts. In order to do so, we wrote a few regular expressions to identify the surnames of the actors and a few simple rules like "the name of a person always precedes his/her surname" or "the role of an actor always follows his/her name". These and a few more rules, combined with the regular writing style of the Diary, allowed us to extract the information from the data with great accuracy. For this extremely domainspecific research in fact, we could not employ other pre-trained models for NER such as the ones available in Spacy (https://spacy.io/models/it). In fact, these models are trained on very general domains such as Wikipedia articles or news; and to identify only the most popular named-entity categories such as dates, location names etc. In order to employ these models for our task, we would have had to re-train them on our domain-specific corpus. Furthermore, to perform the training, we would have had to create a large set (thousands) of labelled training samples featuring the named-entity labels that we employ in our research but were missing in the public model (i.e. the roles of political actors). For the above reasons, we opted for the development of an $a d-h o c$ and simpler tool for NER.

Acknowledgements We would like to thank the graduating students of the Department of Political Sciences, Communication Sciences and Information Engineering/Department of Law at the University of Sassari employed in the Research Lab "Analisi Presidente della Repubblica e Presidente della Regione Sardegna" (APRE ${ }^{2}$ ), for their hard work and commitment to the project for the years 2016-2020. We also 
thank the anonymous reviewers for their careful reading of our manuscript and their many insightful comments. As usual, all errors remain ours.

Funding Open access funding provided by Università degli Studi di Sassari within the CRUI-CARE Agreement. The research has been funded by the project entitled "Processi di Presidenzializzazione: la Presidenza della Repubblica italiana e della Regione Sardegna” (Scientific Coordinator: Mauro Tebaldi; Project Coordinator: Marco Calaresu), sponsored by the Regione Autonoma della Sardegna under the Law 7/2007, "Promozione della ricerca scientifica e dell'innovazione tecnologica in Sardegna" (CUP: J72I15000080007CRP: 79130_Codice UGOV: LR72013TEBALDI). Leading institution: University of Sassari, Department of Political Sciences, Communication Sciences and Information Engineering/Department of Law. Total duration of the project: 60 months (2016-2021).

\section{Declarations}

Conflict of interest The authors declare that they have no conflict of interest.

Open Access This article is licensed under a Creative Commons Attribution 4.0 International License, which permits use, sharing, adaptation, distribution and reproduction in any medium or format, as long as you give appropriate credit to the original author(s) and the source, provide a link to the Creative Commons licence, and indicate if changes were made. The images or other third party material in this article are included in the article's Creative Commons licence, unless indicated otherwise in a credit line to the material. If material is not included in the article's Creative Commons licence and your intended use is not permitted by statutory regulation or exceeds the permitted use, you will need to obtain permission directly from the copyright holder. To view a copy of this licence, visit http://creativecommons.org/licenses/by/4.0/.

\section{References}

Aliboni, R.: Neo-nationalism and neo-Atlanticism in Italian foreign policy. Int. Spect. 38, 81-90 (2003). https://doi.org/10.1080/03932720308457015

Amoretti, F., Giannone, D.: The power of words: the changing role of the Italian head of state during the second Republic. Mod. Italy 19, 439-455 (2014). https://doi.org/10.1080/13532944.2014.966810

Amoretti, F., Giannone, D.: Verso una Presidenza mediatica? Il potere di moral suasion del Capo dello Stato dalla crisi della Prima Repubblica ad oggi. Comun. Pol. 17, 65-86 (2016)

Andreatta, F., Brighi, E., Forcella, I.: The Berlusconi government's foreign policy: the first 18 months. Ital. Pol. 18, 221-236 (2002). https://doi.org/10.3167/ip.2002.180114

Best, J.J.: Who talked to the president when? A study of Lyndon B Johnson. Pol. Sci. Q. 103, 531-545 (1988). https://doi.org/10.2307/2150762

Best, J.J.: Who talked with President Kennedy? Interac. Anal. Pres. Stud. Q. 22, 351-369 (1992)

Brighi, E.: Foreign Policy, Domestic Politics and International Relations: The Case of Italy. Routledge, Abingdon (2013)

Caggiula, C., Benedetti, R.: Il Ministero degli Affari Esteri. La Nuova Italia Scientifica, Roma (1992)

Calise, M.: La personalizzazione presidenziale. Il Mulino 62, 460-468 (2013)

Carbone, M.: The domestic foundations of Italy's foreign and development policies. West Eur. Pol. 30, $903-$ 923 (2007). https://doi.org/10.1080/01402380701500371

Carlsnaes, W.: Foreign policy. In: Carlsnaes, W., Risse, T., Simmons B.A. (eds.) Handbook of International Relations, pp. 331-350. SAGE Publications, London (2002)

Cheli, E.: Il capo dello Stato: un ruolo da ripensare? Il Mulino 62, 436-443 (2013)

Cladi, L., Webber, M.: Italian foreign policy in the post-cold War period: a neoclassical realist approach. Eur. Sec. 20, 205-219 (2011). https://doi.org/10.1080/09662839.2011.565052

Čmakalová, K., Rolenc, J.M.: Actorness and legitimacy of the European Union. Coop. Confl. 47, 260-270 (2012)

Collobert, R., Weston, J., Bottou, L., Karlen, M., Kavukcuoglu, K., Kuksa, P.: Natural language processing (almost) from scratch. J. Mach. Learn. Res. 12, 2493-2537 (2011)

Coticchia, F., Davidson, J.W.: The limits of radical parties in coalition foreign policy: Italy, hijacking, and the extremity hypothesis. Foreign Policy Anal. 14, 149-168 (2018). https://doi.org/10.1093/fpa/ orw019 
Coticchia, F., De Simone, C.: The war that wasn't there? Italy's 'peace mission' in Afghanistan, strategic narratives and public opinion. Foreign Policy Anal. 12, 24-46 (2016)

Croci, O.: Much ado about little: the foreign policy of the second Berlusconi government. Mod. Italy. 10, 59-74 (2005a). https://doi.org/10.1080/13532940500113375

Croci, O.: The 'Americanization' of Italian foreign policy? J. Mod. Ital. Stud. 10, 10-26 (2005b)

Croci, O.: The second Prodi government and italian foreign policy: new and improved or the same wrapped up differently? Mod. Italy 13, 291-303 (2008). https://doi.org/10.1080/13532940802185014

Croci, O., Valigi, M.: Continuity and change in Italian foreign policy: the case of the international intervention in Libya. Contemp. Ital. Polit. 5, 38-54 (2013). https://doi.org/10.1080/23248823.2013.781373

De Vergottini, G.: Politica estera e interventi del Presidente della Repubblica. Quad. Cost. 4, 493-523 (1984)

De Vergottini, G.: Sicurezza internazionale: un correttivo presidenziale. Per. Costit. 2-3, 83-110 (2011)

Diani, M.: Networks and social movements: a research programme. In: Diani, M., Mcadam, D. (eds.) Social Movements and Networks: Relational Approaches to Collective Action, pp. 299-319. Oxford University Press, New York (2003)

Eckstein, H.: Case studies and theory in political science. In: Greenstein, F.I., Polsby, N.W. (eds.) Handbook of Political Science: Scope and Theory, pp. 94-137. Addison-Wesley, Reading (1975)

Edwards, G.C., III., Wayne, S.J.: Presidential Leadership: Politics and Policy Making, $2^{\text {nd }}$ ed. St. Martin's Press, New York, NY (1990)

Emirbayer, M., Goodwin, J.: Network analysis, culture, and the problem of agency. Am. J. Sociol. 99, 1411-1454 (1994). https://doi.org/10.1086/230450

Esser, F., Strömbäck, J. (eds.): Mediatization of Politics: Understanding the Transformation of Western Democracies. Palgrave Macmillan, London (2014)

Franzosi, R.: Narrative as data: linguistic and statistical tools for the quantitative study of historical events. Int. Rev. Soc. Hist. 43, 81-104 (1998a)

Franzosi, R.: Narrative analysis: or why (and how) sociologists should be interested in narrative. Annu. Rev. Sociol 24, 517-554 (1998b)

Franzosi, R.: The return of the actor: Interaction networks among social actors during periods of high mobilization (Italy, 1919-1922). Mobilization 4, 131-149 (1999). https://doi.org/10.17813/maiq.4. $2.480 \mathrm{~g} 127005356631$

Franzosi, R.: From Words to Numbers: Narrative, Data, and Social Science. Cambridge University Press, Cambridge (2004)

Franzosi, R.: Quantitative Narrative Analysis. SAGE, Thousand Oaks (2010)

Franzosi, R.: On quantitative narrative analysis. In: Holstein, J.A., Gubrium, J.F. (eds.) Varieties of Narrative Analysis, pp. 75-98. SAGE, Los Angeles (2012)

Franzosi, R., De Fazio, G.D.E., Vicari, S.: Ways of measuring agency: an application of quantitative narrative analysis to lynchings in Georgia (1875-1930). Sociol. Methodol. 42, 1-42 (2012). https:// doi.org/10.1177/0081175012462370

Fusaro, C.: La formazione del governo Monti e il ruolo del Presidente della Repubblica. In: Bosco, A., Mcdonnell, D. (eds.) Politica in Italia, 2012 edizione, pp. 83-100. Il Mulino, Bologna (2012)

Galliani, D.: I sette anni di Napolitano. Evoluzione politico-costituzionale della Presidenza della Repubblica. Egea/Università Bocconi, Milano (2012)

George, A.L.: Bridging the Gap between Theory and Practice. Institute for Peace, Washington (1993)

George, A.L.: The two cultures of academia and policy-making: bridging the gap. Pol. Psychol. 15, 143171 (1994). https://doi.org/10.2307/3791443

George, A.L., Bennett, A.: Case Studies and Theory Development in the Social Sciences. MIT Press, Cambridge (2005)

Gerring, J.: Case Study Research. Cambridge University Press, New York (2007)

Giannone, D., Cozzolino, A.: La costruzione dell'Europa nella narrazione del Presidente della Repubblica. Uno studio esplorativo sui discorsi di fine anno (1949-2019). Quaderni Sci. Pol. 28, 35-61 (2021)

Greco, E., Matarazzo, R.: Italy's European policy and its role in the European convention. Int. Spect. 38, 125-135 (2003). https://doi.org/10.1080/03932720308457041

Grimaldi, S.: Italy in the narration of President Napolitano. Comun. Pol. 12, 73-94 (2011)

Grimaldi, S.: The leadership capital of Italian presidents: The politics of constraints and moral suasion. In: Bennister, M., Worthy, B., Hart, P.T. (eds.) The Leadership Capital Index. A New Perspective on Political Leadership, pp. 226-249. Oxford University Press, Oxford (2017)

Groenleer, M.L.P., Van Schaik, L.G.: United we stand? The European Union's international actorness in the cases of the international criminal court and the Kyoto Protocol. J. Common Mark. Stud. 45, 969-998 (2007). https://doi.org/10.1111/j.1468-5965.2007.00756.x 
Hopcroft, J.E., Motwani, R., Ullman, J.D.: Introduction to Automata Theory, Languages, and Computation. Pearson/Addison-Wesley, Boston (2006)

Hudson, V.M.: Foreign policy analysis: actor-specific theory and the ground of international relations. Foreign Policy Anal. 1, 1-30 (2005). https://doi.org/10.1111/j.1743-8594.2005.00001.x

Ignazi, P.: Al di là dell: Atlantico, al di qua dell'Europa. Dove va la politica estera italiana. Il Mulino 53, 267-277 (2004)

Kaarbo, J.: A foreign policy analysis perspective on the domestic politics turn in IR theory. Int. Stud. Rev. 17, 189-216 (2015)

King, G., Keohane, R.O., Verba, S.: Designing Social Inquiry: Scientific Inference in Qualitative Research. Princeton University Press, Princeton (1994)

Knoke, D., Song, Y.: Social Network Analysis. SAGE, Thousand Oaks (2008)

Lansdall-Welfare, T., Sudhahar, S., Thompson, J., Cristianini, N.: The actors of history: narrative network analysis reveals the institutions of power in British society between 1800-1950. In: Adams, N.M., Tucker, A., Weston, D.J. (eds.) Advances in Intelligent Data Analysis XVI. IDA. Lect. Notes Comput. Sci. 10584, pp. 186-197. Springer, Cham (2017). https://doi.org/10.1007/978-3-319-68765-0_16

Levy, J.S.: Case studies: types, designs, and logics of inference. Confl. Manag. Peace Sci. 25, 1-18 (2008). https://doi.org/10.1080/07388940701860318

Link, M.W., Kegley, C.W., Kegley, J.R.: Is access influence? Measuring adviser-presidential interactions in light of the Iranian hostage crisis. Int. Interact. 18, 343-364 (1993). https://doi.org/10.1080/03050 629308434813

Lippolis, V., Salerno, G.M.: La repubblica del Presidente. Il settennato di Giorgio Napolitano. Il Mulino, Bologna (2013)

Manning, C., Schutze, H.: Foundations of Statistical Natural Language Processing. MIT press (1999)

Mazzoleni, G., Schulz, W.: Mediatization of politics: a challenge for democracy? Polit. Commun. 16, 247261 (1999)

Mcclosky, H.: Concerning strategies for a science of international politics. World Pol. 8, 281-295 (1956). https://doi.org/10.2307/2008975

Palladino, N.: 'Presidentialisations' in Italy: the battle for leadership between the Prime Minister and the President of the Republic. Contemp. Ital. Pol. 7, 107-126 (2015). https://doi.org/10.1080/23248823. 2015.1036544

Pasquino, G.: Italian presidents and their accordion: pre-1992 and post-1994. Parl. Aff. 65, 845-860 (2012). https://doi.org/10.1093/pa/gsr059

Poguntke, T., Webb, P.: The Presidentialization of Politics: A Comparative Study of Modern Democracies. Oxford University Press, Oxford (2007)

Scaccia, G.: Il 'settennato' Napolitano fra intermediazione e direzione politica attiva. Quad. Cost. 33, 93-110 (2013)

Schneider, C.Q., Wagemann, C.: Qualitative comparative analysis (QCA) and fuzzy-sets: agenda for a research approach and a data analysis technique. Comp. Sociol. 9, 376-396 (2010). https://doi.org/10. 1163/156913210X12493538729838

Serra, E.: La burocrazia della politica estera italiana. In: Bosworth, R.J.B., Romano, S. (eds.) La Politica Estera Italiana/1860-1985, pp. 69-89. Il Mulino, Bologna (1991)

Sigelman, L., Mcneil, D.M.: White house decision-making under stress: a case analysis. Am. J. Pol. Sci. 24, 652-653 (1980). https://doi.org/10.2307/2110952

Smelser, N.J.: Comparative Methods in the Social Sciences. Prentice Hall, Englewood Cliffs (1976)

Tebaldi, M.: Il Presidente della Repubblica. Il Mulino, Bologna (2005)

Tebaldi, M.: Il potere di esternazione del capo dello Stato nella Seconda Repubblica. Comun. Pol. 15, 485505 (2014a)

Tebaldi, M.: From notary to ruler: the role of the President of the Republic during the Italian crisis (20102014). South Eur. Soc. Pol. 19, 561-581 (2014b). https://doi.org/10.1080/13608746.2014.992770

Tebaldi, M., Calaresu, M., Purpura, A.: Con chi parla il Presidente? Un'analisi relazionale del Diario di Giorgio Napolitano (2006-2013). Comun. Pol. 19, 333-372 (2018)

Tebaldi, M., Calaresu, M., Purpura, A.: The power of the president: a quantitative narrative analysis of the diary of an Italian head of state (2006-2013). Qual. Quant. 53, 3063-3095 (2019). https://doi.org/10. 1007/s11135-019-00920-7

Tebaldi, M.: Poteri e prassi del Presidente della Repubblica nel sistema politico italiano. Interpretazioni dell'esperienza maggioritaria. Diritto e Questioni Pubbliche 11, 417-462 (2011)

Varsori, A.: The foreign policy of first Republic Italy: new approaches. J. Mod. Ital. Stud. 20, $292-297$ (2015). https://doi.org/10.1080/1354571X.2015.1026139

Walston, J.: Italian foreign policy in the 'Second Republic'. changes of form and substance. Mod. Italy 12, 91-104 (2007). https://doi.org/10.1080/13532940601134916 
Walston, J.: Foreign policy: the difficult pursuit of influence. Italian Polit. 23, 123-140 (2007b)

Waltz, K.N.: Theory of International Politics. Addison-Wesley, Reading (1979)

Waltz, K.N.: Reflections on theory of international politics: A response to my critics. In: Keohane, R.O. (ed.) Neorealism and Its Critics, pp. 322-345. Columbia University Press, New York (1986)

Wasserman, S., Faust, K.: Social Network Analysis Methods and Applications. Cambridge University Press, Cambridge (1994)

Zucconi, M.: Italy. In: Hocking, B., Spence, D. (eds.) Foreign Ministries in the European Union: Integrating Diplomats, pp. 163-176. Palgrave Macmillan, Basingstoke (2002)

Publisher's Note Springer Nature remains neutral with regard to jurisdictional claims in published maps and institutional affiliations. 